\title{
Implications of United States - China Trade War to Indonesia
}

\author{
Humphrey Wangke \\ Indonesia Parliamentary Expertise Board, Jakarta, Indonesia
}

Email address:

dhanny_2000@yahoo.com

\section{To cite this article:}

Humphrey Wangke. Implications of United States - China Trade War to Indonesia. International Journal of Business and Economics Research. Vol. 9, No. 3, 2020, pp. 151-159. doi: 10.11648/j.ijber.20200903.18

Received: January 30, 2020; Accepted: May 11, 2020; Published: May 29, 2020

\begin{abstract}
The trade war between the United States (US) and China is occurred at the time the two countries has mutually apply the additional effective tariffs since the beginning of September 2019 on comodity they trade. This trade war could have positive and negative impacts to Indonesia. The positive is Indonesia has potentialy become an industrial countries destination that departs from China to find a new locations. The negative is the demand of raw materials nor the comodity from Chinese to Indonesia will be decrease. This article is a result of research in East Java and South Sumatra Province in 2019. The analysis in this paper is based on the research results using the qualitative methods. The Data collection techniques conducted through the interviews on field with random selected respondents, the field observations and the literature studies. The field research was carried out with the purpose of analyzing the implications of the US-China trade war toward Indonesia. The results of the study shown that Indonesia is transforming its finances in order to remain competitive in global economic uncertainty due to the trade war. In order to meet this need, several steps taken by Indonesia including the regulations harmonization, strengthen the national economy on an inclusive basis and Indonesia's economic diplomacy.
\end{abstract}

Keywords: United States - China Trade War, Regulations Harmonization, Economic Diplomacy, Protectionism, Economy Transformation

\section{Introduction}

Entering year 2017 the world sees the dramatic changes on the international politics constellation which will be affecting the global trade patterns. Started with the Britain's referendum which in favor of the Britain's exit from the European Union, the world community further saw the United States Presidential's election which resulting the victory of the Republican Party's presidential candidate Donald Trump. During the election campaign, Donald Trump very diligently issuing statement with the protectionist tendency, particularly in threatening China, Mexico and Germany with the import tax. The other surprising decision from President Trump are the executive order to pulling out US from the Trans-Pacific Partnership, although this move is considering more symbolic due to the US Congress has not been ratified the agreement.

Entering year 2019, the tensions between the countries, the political and economy tension in the country as well as the economy power showdown among the countries are continues to undermine the world in solving the humanitarian issues. The development of the digital economy is feared will have impact to the employments, the employment disruption, which will be slowing down the world in resolving the poverty issues. On the other side the poverty that arise as a consequence of the immigration caused by the political pressure which has not been successfully resolved in many countries. Meanwhile the challenges of the climate changes are still continued along with the massive industrial chemical waste threat to human's life.

On these conditions, the global economic is facing the pressure due to a number of countries experiencing the national politic turmoil or involving the conflicts with other country, whether in both geo-economic nor the geo-politic. The protectionism policy, the financial tightening or the increase of the debt burdens in a number of countries have increased the risk of the world economy which predicted to slow down. The international economy tension one of the triggered is the United States - China trade war, two countries with largest economy in the world and therefore are 
the key of the global stability of development and prosperity [1].

United States and China began to engaged in the international economy competition while the two countries racing to form trade partner on the Indo-Pacific region through various initiatives they conducted [2]. China's initiative as Belt and Road Initiative wished to integrate the economy of the countries in Indo-Pacific region by ignoring the United States, the country that always has been a major player in Asia and an integral part of the regional economy. On the contrary the Trans Pacific Partnership's concept led by United States excluded China, country with the largest economy in Asia.

The competition between both countries has developed into trade war at the moment the United States increase the import tariff for China's product that enter the territory of the United States on the grounds of trade deficiency with China are increasing, the unfair trade practices, the poor treatment towards the foreign companies, and the adequate legal and institutional infrastructure to protect the Intellectual Property Rights. Two countries continued to resolve this issue in several round of negotiations, however the United States decided to imposed the additional tariff to China's import product. China immediately responded by increase the import tariff of the product from United States. This situation which came to be known as term "trade war" [3].

Until when the condition of this trade war will last it is still difficult to be predicted due to it will be depend on the loss bear by one of the party. The faster and the greater lost, the higher the desire of both parties to settled. Moreover, this trade war takes place face to face (head to head), hence it is difficult to be expected to resolved bilaterally in the near future even though the impact can be felt directly by the world community.

For Indonesia, whether the United States nor China are the main trading partner, hence arise the concern that the trade war United States - China will be affecting the Indonesian foreign trade. Indonesia trade with China always record the deficiency whilst with the United States recorded a surplus. Based on the data from the Indonesian Ministry of Trade year 2019, the trade balance between Indonesia and China on year 2017 experienced the deficiency in amount of US\$ 12,76 billion with the details of the total trade between Indonesia China in 2017 in amount of the US\$ 58,82 billion, with Indonesian's import value approximately in amount of US\$ 35,76 billion while the export in amount of the US\$ 23 billion. Whilst with the United States, Indonesia recorded a surplus in amount of US\$ 9,66 billion, with the details of import in amount of US\$ 8,12 billion and the export in amount of US\$ 17,79 billion.

With this background, this paper will analyze the implications of the United States -China trade war towards Indonesia. By discussing this question, this paper purpose is to analyze the steps that Indonesia needs to take in order to overcome the implications of the United States - China's trade war. Domestically, Indonesia shall be able to improve its economy so that the manufacturing products' produces be able to compete with the similar products in the international market. In addition, Indonesia shall also be able to utilize its diplomats in order to actively carry out the economic diplomacy to open the foreign markets and attracted foreign investors to Indonesia.

\section{Method}

The analysis in this paper based on the research result using the qualitative methods. The data collected in this research are the primary data and the secondary data. The primary data acquired through interview on the fields and observation, whilst the secondary data acquired through the literature studies. In order to obtain primary data, the Researcher conducted interview which the source have randomly selected, whether from the government element both from central and regional along with the economy actors. The validation of the data conducted by questioning the same question to different information's source and proceed with the fields observation.

The research conducted in East Java and South Sumatera Province on June 2019. Both province selected as the research location due to it has different commodity character which heavily dependent on the United States and China as the export destination countries. The export of East Java Province has been formed on finished goods or semi-finished goods, whilst the South Sumatera still dominated by raw materials.

\section{Result}

\subsection{Trade War and the Settlement}

When in regard to the various existing literature, the analysis towards the trade war between the states is not something new. The conflicts between the state are driven by the economic interests which often occurred. Various definition has been given by the experts at the time they wished to analyze further more about the cause, impacts and the solutions which should be done in order to overcome it. There are some opinion that defines the trade war as " the increase of trade protectionism through tariff and non-tariff mechanism, such as increase on the import taxes and the export subsidies" [4]. The problem that arising from the protectionism is the countries which are targeted by the protectionist actions will take retaliatory measures.

On other definitions of trade warfare were refer to as "intense international conflict in in which the state interacts, bargains, and retaliates primarily for the economy objectives directly related to the goods or services traded, and the way that utilized is the restrictions on the free flow of goods and services [5]. Furthermore according to Conybeare, there are 3 impacts of the trade war as follow: first, trade war that will harm the parties involved, second, the trade war between the large and the small countries, in this condition the large countries will gained the benefit, and third, the trade war which involving the large number of countries [6]. 
On the trade war at this time, the United States import tariff to China's exporters has been responded by China in a same way towards the United States' exporters. These unilateral's actions taken is often understood as protectionism, and it has been assessed as a violation of the WTO's regulation due to it violating the basic principles of WTO Chartered which stated that the violation of free trade, fairness and reciprocity shall be analyzed and resolved through the Dispute Settlement Board on the WTO [7]. In the trade war between the United States - China, the purpose of the Trump's government to imposed the import tariffs on China's goods is to encourage the relative competitiveness to the United States' manufacture industry, in which will resulting the higher domestic market share and will create jobs for the United States citizens.

According to Article 301 of the United States' Trade Law, they have the right to impose the trade protection if the partner country does not expand the United States opportunities in the domestic market. President Trump using this article to push China in order to reduce its exports to the United States and floated the Yuan's exchange rate by $40 \%$ in order to create the balance on trade between the two countries. For the United States, which the need of a fair trade, reciprocity, and well balanced. In that way both parties have an obligation to carry it out. By raising the import tariffs, then the Chinese products become more expensive at the time entering the United States' domestic market.

The United States' act of unilateralism seen as a discriminatory by numbers of countries, including China due to it is a violation of the regulations issued by the WTO [8]. These conditions are not in consistent with Article 23 (a) of the WTO's Trade Dispute Resolution which requires each WTO member states to submit a complaints to the agency and does not take its own action or unilateral action. The WTO's dispute resolution institutions in the process have the authority to adjudicate, and resolve any disputes between the member countries. Each country whoever feel grieved by the treatment of other countries, shall be reported to the WTO, instead of taking steps unilaterally. The concern is that the United States' act of retaliation against China, if its neglected, automatically can be done to all countries. Other concern is the act taken by the United States may be followed by other countries.

Facing the increase of protectionist measures and the potential trade war in the major countries, policy makers in developing countries trying to cope with the implications that may arise. There are several options that the countries be able to make in order to overcome the implication of the trade war, is as follow:[9] join the trade war and conduct the retaliation; doing nothing; pursuing the trade agreements with the countries outside the United States region; pursuing the trade agreements with countries outside the United States region and unilaterally liberalize the import tariffs from the United States.

For Indonesia the selection of the most visible and politically uncontroversial is doing nothing and pursuing the trade agreements with the countries that are outside the
United States' region. If it restraint, then Indonesia will be able to get benefit from the diversion arising from the trade war between those two great country. Instead, the loss will be greater if imposing measures of retaliation, due to the impacts of the trade war.

The policy makers in developing countries can conduct proactively in order to repair the destructive impact of the increase of the trade restrictions whether internally and externally. Strengthening the domestic economy and expanding the export markets are the best options for Indonesia and other developing countries in order to overcome the effects of the United States - China trade war.

From the discussion on trade warfare and its resolution through the WTO, the author will further discuss the implications of trade warfare towards Indonesia. However before that, the author will provide a narrative of the research result on the trade conditions in East Java and South Sumatra Provinces with the United States and China. From the trade conditions' narrative in the two provinces, the author analyzed the implications of the United States and China's trade war to Indonesia.

\subsection{The Potential of Foreign Trade in East Java Province and South Sumatra Province}

\subsubsection{East Java Province}

The United States has become one of the 10 (ten) main export destination countries of East Java Province in the past five years. The trade balance of East Java - United States during the period of 2014 - May 2018 always shown a surplus for East Java. The highest surplus was occurred in 2017 in amount of US\$ 1,035.19 million. In the period of January-May 2018 the export value of non - oil and gas in East Java to United States has reached US\$ 1062.91 million, and has contributed for $14.06 \%$ of the total export of non - oil and gas in East Java, which reached US\$ 8026.62 million. The East Java Province's trade with the United States are presented on the below Table 1.

Table 1. East Java - United States Trade Balance Year 2014-2018 (in US\$ million).

\begin{tabular}{llll}
\hline Year & Export & Import & Surplus / Deficit \\
\hline 2014 & $2,0005.95$ & $1,477,30$ & 528.62 \\
2015 & $1,881.03$ & $1,291.36$ & 589.67 \\
2016 & $1,999.48$ & $1,143,56$ & 855.92 \\
2017 & $2,337.90$ & 1302.81 & 1035,19 \\
$2018 *$ & $1,062.91$ & 587.03 & 475.88 \\
\hline
\end{tabular}

* Data January - May 2018

Source: East Java Trade Agency, 2019.

The statistics data on table 1 shown that the profit of the East Java Province is increasing every year. The main exports commodity of non - oil and gas from East Java to the United States are include fish and shrimp; home furniture and lighting; processed meat and fish; aluminum; cocoa/chocolate; jewelry/gems; various chemical products; vehicles and parts; animal/vegetable fats \& oils; electrical machinery/equipment. The main import commodity of non - 
oil and gas in East Java from the United States are include greasy grain; food industry residue/waste; inorganic chemicals; machineries/mechanical aircraft; artificial staple fiber; oats; wood pulp/pulp; electrical machinery/equipment; milk, butter, eggs; iron and steel.

Besides the United States, China is also one of the largest trading partner for East Java Province. The statistics shown that China were among the 10 (ten) of main export destination countries of East Java over the past five years. If with the United States, East Java obtain the surplus which is the opposite with China during the period 2014 - May 2018 which always shown the deficiency. The highest deficit was occurred in 2017 in amount of US\$ 3,263.11 million. In period of January - May 2018 the export value of non - oil and gas in East Java to China was reached the amount of US\$ 778.02 million, which is up to $21.33 \%$ from the same period the previous year, and contributed for $10.10 \%$ of the total exports of non - oil and gas of East Java which is reached US\$ 8026.62 million. Below table shown the trade balance of East Java Province with China.

Table 2. East Java - China Trade Balance 2014 - 2018 (in US\$ million).

\begin{tabular}{llll}
\hline Year & Export & Import & Deficit \\
\hline 2014 & $1,911.48$ & $4,341.08$ & $(2,429,60)$ \\
2015 & $1,495.79$ & $3,865.45$ & $(2,369.66)$ \\
2016 & $1,569.01$ & $4,219.33$ & $(2,650.32)$ \\
2017 & $1,743.90$ & $5,007.01$ & $(3,263.11)$ \\
$2018 *$ & 778.02 & $2,329.66$ & $(1,551.64)$ \\
\hline
\end{tabular}

*) Data January - May 2018

Source: East Java Province Trade Agency, 2019.

The main of non-oil export of East Java to China among others oil \& animal/ vegetable oil; timber and its derivatives; copper; various chemical products; organic chemical material; fish and shrimp; footwear; milk, butter, egg; paper/cardboard; plastic and plastic product. The main commodities imported from China in East Java are: machine and electrical equipment; machine-machine; iron and steel and its derivatives products; aluminium; fruits; plastic and plastic products; organic chemical material; fertilizer; inorganic chemical material.

\subsubsection{South Sumatera Province}

The foreign trade has an important role in the economy and development, especially the exports are one of the biggest sources of foreign exchange income. With foreign exchange income, the country or region will be able to buy imported goods needed for the consumption and support the industrial sector. So far China has become the main export destination for the South Sumatra Province for the non - oil and gas sector with the leading commodities such as rubber, coffee and cocoa, followed by Malaysia and the United States, each with US\$ 419, 84 million, US\$ 125.48 million and US\$ 114.96 million. The role of these three countries reached $50.28 \%$ for early 2019 .

The abroad trade balance of South Sumatera Province has never experienced deficit, its always surplus because its main export commodities are still raw materials. Even though the
United States and China are involved in a trade war, the South Sumatra Province are still able to take advantage by maintaining the surplus value which it has been experiencing in the past 2 years. The Table 3 below shown the surplus value of the South Sumatera Province with 4 main export destination countries in the last 2 years.

Table 3. South Sumatra Trade Surplus with Four Countries Year 2017 - 2018 (Million US\$).

\begin{tabular}{llll}
\hline \multirow{2}{*}{ Country of destination } & \multicolumn{2}{l}{ Surplus } & $\begin{array}{l}\text { Change } \\
\text { (\%) }\end{array}$ \\
\cline { 2 - 3 } & $\mathbf{2 0 1 7}$ & $\mathbf{2 0 1 8}$ & 32.54 \\
\hline China & 840.83 & $1,114.45$ & 81.76 \\
Malaysia & 270.70 & 492.02 & -26.86 \\
United States of America & 412.08 & 301.39 & 6.83 \\
India & 293.43 & 313.48 & 22.25 \\
Total & $1,817.03$ & $2,221.34$ & \\
\hline
\end{tabular}

Source: The Foreign Trade Statistics of South Sumatera Province, BPS, 2018

In contrast with East Java Province, the South Sumatera Province actually gained profits from the foreign trade with China, whilst with the United States suffered losses. Based on the Foreign Trade Statistics' data published by the Indonesia Central Statistics Agency (BPS) in 2018, the value of South Sumatera exports in 2017 and 2018 are increased because the prices of key export commodities such as rubber and palm oil are began to improve on the international market, as well as new commodities are being exported, such as: pulp/pulp. In 2018, the biggest surplus is coming from the trade balance with Chinese trading partners of $1,114.45$ million US\$, a significant increase of $32.54 \%$ compared to 2017, which was 840.83 million US\$.

The magnitude of this surplus is not yet fully demonstrated the competitiveness of the South Sumatera Province in the international market considering the exported products are still in form of raw materials [10]. In the future, the South Sumatera has to consider the superior manufacturing products. The tire production can be considered in view that the South Sumatera traditionally has been the largest rubber producing province in Indonesia.

Facing the unpredictability of the world trade as a result of the United States - China's trade war, it is time for Indonesia to develop the national manufacturing industry that have capability of producing the excellent products with the supply of raw materials from within the country in a sustainable manner. In view of the natural conditions of South Sumatera as the largest producer of natural rubber in Indonesia, Indonesia can establish a tire factory and carry out protection, for an example by require the motorcycle users to use the domestic production [11]. By utilizing the domestic market, Indonesia will be able to avoid the impacts of the trade war. This is not only to avoid the trade war, but also to strengthen the domestic economy.

\section{Discussion}

\subsection{Regulation Harmonization}

The trade war occur because China's domestic market is so 
protective that caused the United States' manufacturing products are practically difficult to penetrate. How does China protect its domestic market? China has formally opened its domestic market for the imported products, but that was done after its manufacturing products has taken control of the domestic market. The producent like Alibaba has grown by dominating the domestic market, afterward the Amazon may enter the market. The enterprise social media such as Baidu, Weibo, Youku Tudou and RenRen has controlled $80 \%$ of the domestic market afterward Youtube and Facebook may enter the market. As for the electronics, China has developed Huawei, Oppo, Xiaomi and Lenovo, afterward the new companies from abroad may enter the market. Likewise for the online transportation, China has developed the new Didi Chuxing, afterward Uber may enter. With such conditions, anyone who enter the market they must adjust. So it is not exaggerated if China issued very strict new guidelines on patent protection, copyright and other intellectual property. Indonesia should be able to do such thing. The most likely way to do this is exploit the potential of the domestic economy through the consumer power and increased of the investment.

The effort to increase the investment are still requires serious attention, especially in the harmonization of regulations. At the central level there are still many regulations are not in line with the regulations in the lower level as well as between the regulations of the ministries and agencies. This condition shall be fixed so it will not caused fragmentation which can confuse the local governments and business actors, considering the business actors need the certainty. The regulations which are not yet harmoniously regulate will only lead to a long bureaucratic service lines and the burden some levies which will create a high cost economy and interfere with the simplicity of doing business. Therefore, the government are committed to harmonizing approximately 72 regulations under the umbrella law, Omnibus Law on Job Creation. The goal is to facilitate the licensing services, removing barriers, and encouraging the increased of investment particularly related to creating of jobs opportunity and the empowerment of the small and medium enterprises.

Beside improving the regulations on investment sector, Indonesia also have to accelerate the process of the economy transformation so that the export products is not dominated by raw materials which are not too profitable. In South Sumatera Province, the people's economy is identic with rubber and coffee. However, ironically the price of these two leading commodities was determined by the buyer, such as the price of rubber determined by Singapore while the price of the coffee determined by Germany. Many export products of South Sumatera Province shipped through Singapore, so Singapore also gained benefit by participating on determines of the price. Therefore, Indonesia should do is to strengthen the domestic industries by creating regulations which in favor of the regional entrepreneurs so that the down streaming business in the regions can run smoothly [12].

For each province to be complementary, the government must avoid inter-island product uniformity. Each province already has economic power to survive, so it needs to be utilized so that it is not affected by trade wars. Second, Indonesia's large domestic market is time to get used to its own products even though the quality is not according to international standards. China initially began building its industry with such conditions, but gradually was able to compete with Japanese products. This can happen because China has from the beginning been very concerned about its products being loved in the country.

Indonesia's strength is in its territory which consist of islands. With the development of the concept of inter-island trade, it has actually become a strength to mutually supply superior products from each province. So each province can be a complementary to each other, the government must avoid the uniformity of the inter-island products. Each region already has its economic strength to survive, and therefore it need to be utilized so it will not be affected by the trade war. Second, it is the time for Indonesia's large domestic market is get used to its own products even though the quality is not according to the international standards. China initially began to build its industry with such conditions, however gradually China were able to compete with the Japanese products. This is happening because China from the beginning has been very concerned about its products are being appreciated or loved in the country.

Third, for the people's economy interests, the government needs to apply the protection in order to ensure the sustainability of small and medium industries in certain sectors. The government needs to create regulations which regulate the utilizing of the local goods so that Indonesia does not have to import. The Indonesian consumers should prioritize the domestic products even though the imported products may be much cheaper than local products [13]. For the development of the local products, the South Sumatera Province links it with the development of the tourism, so the tourists whose come to South Sumatera can buy the local handicraft products. In addition, each mall is also required to provide a place for selling the local products.

\subsection{Strengthening the National Economy Inclusively}

Facing the United States - China's trade war, Indonesia must be careful if it does not want the domestic industry displaced because it does not have any regulations which can be use as a reference in overcoming the impact of the trade war. Indonesia's domestic market is very large because it covers 250 million people, which is equivalent to 50 percent of consumers in the Southeast Asian region. The potential and power should be able to be managed well so that Indonesia did not experience the impact of the trade war. How to manage it? One of it is to engage with all stakeholders, especially the small economic actor such as cooperatives and Small, Medium and Micro Business Enterprises.

The involvement of the small economic actors is to increase their income and especially in order to increase the creativity and innovation of small economic actors. Thus, the 
national trade will be stronger because of the involvement of many economic actors. Especially if in its implementation the government also provides incentives and trade facilities so that the management of the foreign trade will benefits all the stakeholders and most importantly the trade activities become more inclusive because it involves all stakeholders.

Amid the uncertainty of the world economy due to the protectionism, Indonesia still has extraordinary assets that should be utilized to the maximum such as a large domestic market and it continues to grow. With the population of around 250 million, the large domestic market is very vital for the development of Indonesia's geo - economics in the future. This objective condition needs to be capitalized not only for the interests of Indonesia but also establishing the cooperation with other countries. At the same time, Indonesia also have to secure from the illegal products, subsidized or dumping enter into the Indonesian domestic market. The low growth of the global economic at this time potentially increase the violation that should be aware.

The large domestic market it should be Indonesia's bargaining power in establishing mutually beneficial cooperation in bilateral and regional. And for that the economy transformation need to be speed up so the growth of the economy could be higher by developing the growth resources in the country with a focus on manufacturing industries and tourism. Discontinue of the raw materials products and boost the semi-finished goods exports are the strategy that should be done consistently in order to address the deficit on the trade balance.

In order to be more competitive with the similar products from other countries, the trade facilities is also important to be prioritize because it will be an incentive for the exporters. Through such facilitation, the industry players who only sold their products domestically will be more eager to expand the exports due to the incentives. The free trade really requires the cooperation of all the stakeholders because it is not only related to improving the product quality, but also the incentives and facilities itself. Nevertheless, this incentive and facilitation awarding must be done carefully and thoroughly so Indonesia will not trapped in antidumping problem which has been regulated by the WTO so it becomes counter-productive with the exports enhancement.

In the effort of increasing the exports, the government of Indonesia should be able to encourage all the economic actors which own the spirit of market -oriented in order to conduct the export more than import. More than that, all economic actors must have a spirit of keep on improving. In order to improve the quality of the goods, every company nor university shall always conduct a research so that the commodities produced become more competitive. Thus, Indonesia should adjust to the needs of the importing country, particularly related to the quality or the qualifications set by the importing country. Many countries in the world provide the production standards for the goods which you wish to import and Indonesia should be able to meet the requirement in the quality and the quantity.

On the other hand, Indonesia shall be careful in the making of policies especially those related to the commitments to be involved in the international trade. The policy of applying the restrictions through import and export restrictions as well as downstream industry has potentially become a problem in international free trade. Since 2009, Indonesia's policy on halal products and the local element content which has been considered as a non-tariff restrictions for the WTO member countries. The United States has imposed a higher tax on Chinese products because it is considered committed fraud, the similar things can also be applied to Indonesia.

The free trade is a good tool for Indonesia to expand its market, however the is important thing is to do is promotion to various countries, especially those interested in Indonesian manufacturing products [14]. East Java Province has been conducted sale of products to Russia, Belgium, Azerbaijan and other countries of the former colonies of the Soviet Union in Central Asia. Unfortunately, this kind of activities is not well supported by inter - state agencies. The promotion has not been effective due to the embassy that should be able to become Indonesian marketing did not run as expected. Compared with China, the government has a very important role in promoting the cooperatives and small medium enterprises. If the cooperatives and small and medium enterprises are not able to sell, the government of China will intervene in order to assist the selling of the products. Therefore, in order to encourage the successful rate in the free trade, thus the promotion activities need to be supported by coordination and cooperation of all the stakeholders.

The importance of the multi- stakeholder involvement in the implementation of free trade is related to providing the uniformity information. Uniformity of the information is very important in the international trade because it is related to the market access and competitiveness. The Ambassador has an important role so he/she must have the valid information data and comprehensive regarding the supply and demand. The information that must be collected by the Indonesian Embassy abroad, for example, regarding the types of products and the commodities traded, the quality of the products and available commodities. With the existence of such information, then the exporter will be able to provide the products that needed by the market. Indonesian diplomats will be able to mapping out the opportunities that can be taken from the traditional and non-traditional market by utilizing the market intelligence data obtained by the Indonesian representative offices abroad.

Amid the global economy uncertainty, Indonesia continues to seek the opportunities so the performance and the domestic economy growth can be improved or at least maintained. In other words, Indonesia must be able to create a resilient economy so that the external conflicts do not really affecting the domestic conditions. By utilizing the Indonesian domestic market with more than 250 million people are the bargaining power in the negotiations so that Indonesia is not unduly disadvantaged. In such situation, an inclusive spirit by involving all the stakeholders will encourage the economic growth and investment. The concept of inter-state trade has emphasized the principle of fairness and reciprocity, which 
mean that the state will no longer emphasize on the export side without importing.

Fixing the economic conditions in the country is very urgent given that the indirect impact of the United States and China's trade war, especially on the potential decrease on the material demand. East Java is one of the provinces that exported raw materials to China to be processed into finished products which is subject to high import tariffs by the United States. With the decrease of the Chinese exports to the United States, the impact will also reduce East Java's exports. Likewise, with the United States, East Java and other provinces in Indonesia, it is necessary to be aware of the United States move in evaluating the implementation of the General System Preferences for around 124 products. The GSP facilities were enjoyed by East Java include plywood and cotton. However, since 2017 this facility has been stopped by the United States. Currently the position of Indonesia has increased as the G-20 countries, such facilities could be evaluated.

In order to deal with the possibility of the terminating of the GSP facility by the United States, the Ministry of Trade has negotiated with the United States and hope that the conversation will be completed as soon as possible. The Government of Indonesia has sought that Indonesian products will continue to receive the GSP facilities in order to obtain import duty relief for thousands of products in the HS 8- digit category as desired by the US. Of these thousands numbers, there are GSP facilities which will be withdrawn such as tobacco, grease derivatives and biodiesel, chemical products, tires, plywood and wood products, aluminium, and boilers tools.

\subsection{Strengthening Indonesia's Economic Diplomacy}

Indonesia is not a country that is involved in directly in the trade war, however neither the United States nor China is a major trading partner of Indonesia, thus whatever happens in the two countries' economy will inevitably bring risks for Indonesia. It has been certain that the impact of the trade war can be positive or negative. The negative impact if the nature is a second rounds effect that is when the United States and China must reduce some of the products which its raw materials come from Indonesia. Facing this second rounds effect there is no other way for Indonesia to seek for new markets to sell its export products.

Whilst the positive impact is when the trade war made the investors seek for the new land to relocate its investment to the countries that are not involved in the trade war. ASEAN countries such as Indonesia, Malaysia, Thailand and Vietnam must compete in order to attract the investors who leave China. Therefore, Indonesia must be able to provide the attractive offers for the foreign investors. Strengthening its national economy, maintaining the investment climate and creating the conducive situation for the business of international trade amid the uncertainty now become an urgent matter for Indonesia.

The economic diplomacy is one of Indonesia's tools as an effort to expand the export segment and attract the investors.
The purpose is the diplomacy that has been carried out by the stakeholders will have an impact to improve the national welfare [15]. The understanding of the economic diplomacy assuming that the focus of the official diplomatic activities is on the issue of increasing the exports, attracting foreign investment and participating on the work of the international economic organizations such as the activities which are concentrated on recognizing the country's economic interests at the international level. The economic diplomacy, and diplomacy in general, are components of a country's foreign policy. The condition of the world economy which is filled with protectionism and unilateralism is a challenge for Indonesia to achieve the target of economic diplomacy. Therefore, it is time for the Indonesian diplomacy reinforced by giving the specific tasks to the diplomats.

The powerful and active diplomacy will determine the role of Indonesia in global society order. Vice versa, the weak diplomacy will make Indonesia's position not taken into account. The European Union discrimination case against Indonesia's oil palm product as one of interesting example related the importance of the robust and offensive diplomacy. The power of the diplomacy is needed in order to build the new partnerships with friendly countries in the amid of the global uncertainty due to the United States and China trade war. Indonesia has made the economic diplomacy as the first priority of Indonesia's foreign policy in 2019-2024 in order to avoid the slowdown in the world economy.

In order to support the export activities and avoid the impacts of the trade war, the steps taken by Indonesia is to expand the market access through the establishment of bilateral and regional free trade agreements. At least Indonesia has completed four partnership agreements which are still in queue for the ratification process, such as: first, the Comprehensive Economic Partnership Agreement between the Republic of Indonesia and the EFTA States, second, the ASEAN Agreement on Electronic Commerce, third, Indonesia-Australia Comprehensive Economic Partnership Agreement, fourth is Indonesia - Korea Comprehensive Economic Partnership Agreement. By accelerating the ratification of numbers of agreements of partnership with trading partners countries, as well as encourage the utilization of the Free Trade Area which has been there and to conduct the export diversification to the non-traditional markets may be an excellent option to do by Indonesia [16].

The various of CEPA agreements are expected to encourage the Indonesian economy to become more competitive and attractive to the investors. This kind of partnership are needed by Indonesia in the amid of the weakening of the world trade and the continuous uncertainty between the countries in 2019 or in subsequent years. This agreement provides a positive signal to the world that the friendly economic relations through a comprehensive cooperation is the best option to encourage the economic growth. This settlement will increase the diversity of the markets and the investment sources.

On the other hand, the CEPA Agreement has become tools for Indonesia in order to make a changes for the sake of 
accelerating the domestic economic growth to be able to compete globally. The changes are needed so that Indonesia can become the part of the global supply chain [17]. Moreover, Indonesia is not only focused on the completion of the trade discussion, however the important thing is to solve the problem of the industrialization and economic reforms since the CEPA is not just a matter of customs tariffs or standard policies for the goods and services or technical trade. It is time for Indonesia to remove the domestic export barriers. The control is needed so there is no leakage in a trade flow and the mismatches of the import documents at the time claiming its privileges based on the trade agreements. The unfair competition such as subsidies or the export prices lower compared with the domestic prices also need to be avoided.

The bilateral free trade agreement with the four countries will be automatically open the market access so the Indonesian export products can enter the international market without significant barriers. Through the CEPA agreement, Indonesia is ready to become part of the global value chain and ready to compete globally because such agreement is not just an ordinary free trade agreement, but becomes a comprehensive partnership that contains not only trade agreements on goods, services and investment, but also in economic cooperation wider as the Vocational Education Training (VET), the higher education, to the health sector. The cooperation in the form of the CEPA are directed to forming the economic powerhouses in Indonesia by combining the trade and the investment interests. In this way, a long-term mutually beneficial economic relationship will be developed because the CEPA agreement marked there are no tariffs for the trade of goods and/or services.

All this time, the Indonesia's export products are obstructed by various hundreds of specific countries' regulations. In the era of the free trade, the non-tariff barriers are widely used by number of countries in order to protect the market and industry in the country. Often the Indonesia's export destination countries create a regulations to prevent the Indonesian products from entering their markets. The obstacles are usually in the form of technical requirements which must be met before entering their markets. These obstacles are become Indonesia's obstacles to increase its exports.

Facing such situation, the stronger and more active Indonesian diplomacy will help to determine Indonesia's role in the global relations. Vice versa, the weak diplomacy makes Indonesia's position left unnoticed. Indonesia needs more offensive diplomacy in order to build the new partnership in the midst of the global uncertainty due to the United States China's trade war. In this case, it is not only the economic diplomacy which must be prioritized, but the most important thing is that the networking also must be the main force and determinant of the growth of Indonesian trade. The strong diplomacy and networking should be able to seize the export market and the investment.

Therefore it is time for Indonesia to determined strengthen its traditional markets abroad and make a breakthrough in the search for new markets abroad. Africa became the target of Indonesia through the Indonesian - Africa Forum and Indonesia-Africa Infrastructure Dialogue, as well as other regions such as Latin America, South Asia. The innovation and the creativity become the keywords as an effort to increase the volume of the foreign trade. The economic diplomacy is expected to create a significant contribution to Indonesia's efforts to improve the economy.

Indonesia needs the foreign investment in order to carry out the development. While the world economy is increasingly indecisive due to the impacts of the United States - China's trade war, the efforts to attract the investment are not easy. It takes creativity and innovation from the diplomats abroad to attract the investors in order to be willing to invest in Indonesia. By making the economic diplomacy as a mainstream in Indonesia's foreign policy, the Indonesian diplomats must be able to actively develop the market for export products, trade cooperation, attract the investors and promote the tourism. The protectionism and uniteralism actions that strengthened due to the trade war became a challenge which was not easily overcome by Indonesian diplomats.

Of course, beside the economic diplomacy, the government also shall make Indonesia as an investment friendly country. Many investors are still complained about the complicated permits in the region as well as the overlapping regulations will still be the main complaints from the investors. Through the synergy between the hard work of Indonesian diplomats and the improvement of the investment climate, Indonesia's opportunities to create the foreign markets and attract the foreign investors will be improved. If the output of the industry sector can be directed to meet the export demands, the needs and the opportunities of the global markets, thus the industry and the trade can be mutually supportive and reinforcing one another.

\section{Conclusion}

The implication of the United States - China's trade war is an opportunity for Indonesia to make changes on its trade management, so the economic competitiveness does not decrease. This change was made both internally and externally. Internally, Indonesia must be able to harmonizing the regulations related to the economy trade sector as an effort to increase the exports. The existing of the conflicting regulations resulting many investors complains and making it difficult for the exports. The Omnibus law which being enacted by the government will be the right step to end the regulatory uncertainty in Indonesian regulations.

In addition, the government also must be able to involve as many as possible the economic actors in order to stimulate the exports. The government's desire to involve the cooperatives and Micro Small Medium Enterprises (UMKM) is a step forward to increase the participation of the small entrepreneurs in the exports, so the profits are not only felt by the large entrepreneurs. Moreover, the government must create a more diverse export market so that there are more 
opportunities for the Indonesian commodity to compete in the international market. The economic diplomacy has become the main stream in President Joko Widodo's foreign policy in the next 5 years, its clarifies the government's commitment to increase the exports. The key role for the economic diplomacy is in the hands of diplomats to be more active and innovative in seek of the markets and the investors.

\section{Acknowledgements}

1. Yustianus. Head of Trade Agency of South Sumatera Province, Palembang, Indonesia

2. Johanes. Assistant of the Regional Secretary of South Sumatera Province, Palembang, Indonesia.

3. Akbar Alfarah and Viktor Alfonso. Industry and Commerce Chambers of South Sumatera Province, Palembang, Indonesia.

4. Zainal Arifin. Department of Cooperatives and Micro, Small and Medium Enterprises of South Sumatera's Province, Palembang, Indonesia.

5. Zamhadi. Industry and Commerce Chamber of East Java, Surabaya, Indonesia.

\section{References}

[1] "Understanding the US-China Trade War: Analysis and CCG Recommendations", CCG Report, No. 23. 7. 2018.

[2] Wang, Jiang Yu, "Between Power Politics and International Economic Law: Asian Regionalism, the Trans-Pacific Partnership and U.S.-China Trade Relations", Pace Int'l L. Rev. No. 30, 2018, hal. 383-439.

[3] Masahiko Tsutsumi, "The Economic Consequences of the 2018 US-China Trade Conflict: A CGE Simulation Analysis", CIS Discussion Paper Series, No. 672, Center for Intergenerational Studies, Institute of Economic Research, Hitotsubashi University.

[4] Thiebaut, Renata. (2018). An Analysis of the U.S.-China Trade War: How the Section 301 China Intellectual Property Case May Impact New Directives to Promote the 'Made in China 2025'. SSRN Electronic Journal · October 2018, DOI: 10.2139/ssrn.3272153, hal. 15.

[5] Antoine Bouet dan Davis Laborde, "US Trade war with emerging countries in the $21^{\text {st }}$ Century: Make America and Its Partners Lose Again", The International Food Policy Research Institute Discussion Papers, August 2017. See also,
Conybeare, J. A. 1987. Trade Wars: The Theory and Practice of International Commercial Rivalry. New York: Columbia University Press.

[6] Conybeare, ibid.

[7] See, Chad P. Bown and Kara M. Reynolds, "Trade Agreements and Enforcement: Evidence from WTO Dispute Settlement", American Economic Journal: Economic Policy, 2017, 9 (4): 64-100.

[8] Kalim Siddiqui, "US-China Trade: The Reason Behind and its impact on the global economy", The World Financial Review, November - December 2018.

[9] Shantayanan Devarajan, Delfin S. Go, Csilla Lakatos, Sherman Robinson, Karen Thierfelder, "Traders' Dilemma Developing Countries' Response to Trade Disputes", Policy Research Working Paper, 8640, World Bank, Nov 2018.

[10] Interview with Yustianus, the Head of Trade Agency of South Sumatera Province, $10^{\text {th }}$ July 2019, Palembang, Indonesia.

[11] Interview with Johanes, Assistant of the Regional Secretary of South Sumatera Province, $9^{\text {th }}$ July 2019. Palembang, Indonesia.

[12] Explanation from Akbar Alfarah and Viktor Alfonso from Industry and Commerce Chambers, South Sumatera Province, $9^{\text {th }}$ July 2019, Palembang, Indonesia.

[13] Zainal Arifin, Dinas Koperasi dan UMKM of South Sumatera's Province, $10^{\text {th }}$ July 2019, Palembang, Indonesia.

[14] Trade plays an important role in the Indonesian economy. According to the World Bank, despite the global economic slowdown, trade still manages to contribute up to $43 \%$ of Indonesia's total GDP in 2018, amounting up to USD 293 billion.

See, https://data.worldbank.org/indicator/NE.TRD.GNFS.ZS?locati ons. Accessed on 31 Januari 2020.

[15] Maaike Okano-Heijmans, Conceptualizing Economic Dipplomacy: The Crossroads of International Relations, Economics, IPE and Diplomatic Studies, The Hague Journal of Diplomacy 6, 2011, DOI: 10.1163/187119111X566742.

[16] Interview with Zamhadi, the Industry and Commerce Chamber of East Java, KADIN Jatim, 25 ${ }^{\text {th }}$ June 2019, Surabaya, Indonesia.

[17] The 2020 edition of the World Development Report with the theme "Trading for Development in the Age of Global Value Chains" states that Indonesia's participation in the global value chain is still weak because it is still a supplier of raw and mineral goods. 